Article

\title{
Gold nanoparticle stabilization within tailored cubic mesoporous silica: Optimizing alcohol oxidation activity
}

\author{
Wei Hong a, Xiaoqing Yan ${ }^{b}$, Renhong Li a,b, Jie Fan a,* \\ a Key Laboratory of Applied Chemistry of Zhejiang Province, Department of Chemistry, Zhejiang University, Hangzhou 310027, Zhejiang, China \\ ${ }^{\mathrm{b}}$ Key Laboratory of Advanced Textile Materials and Manufacturing Technology, Ministry of Education of China, Zhejiang Sci-Tech University, Hangzhou \\ 310018, Zhejiang, China
}

\section{A R T I C L E I N F}

\section{Article history:}

Received 20 October 2016

Accepted 6 December 2016

Published 5 March 2017

\section{Keywords:}

Gold nanoparticle

Cubic mesoporous silica

Entrance size

Anti-sintering property

Alcohol oxidation

\begin{abstract}
A B S T R A C T
Stabilizing gold nanoparticles (AuNPs) within a desired size range is critical to realize their promising catalytic performance in many important reactions. Herein, we investigate the anti-sintering properties of cubic mesoporous silica (FDU-12) as a function of pore entrance size. Simple adjustments to the type of organic template and reaction temperature enable the successful synthesis of FDU-12 with controllable entrance sizes $(<3,3-5$ and $7 \mathrm{~nm})$. Excellent anti-sintering properties are observed for FDU-12 with a sub-5-nm entrance size (3-5 $\mathrm{nm}$ ) over a wide loading concentration (1.0-8.3 wt\%) and the AuNPs can be stabilized within a 4.5-5.0-nm range after calcination at $550{ }^{\circ} \mathrm{C}$ in air for $5 \mathrm{~h}$. Smaller entrance size $(<3 \mathrm{~nm})$ prevents ingress of 3-nm AuNPs to the mesopores and results in low loading capacity and sintering. Conversely, FDU-12 possessing a larger entrance size $(7 \mathrm{~nm})$ shows promising anti-sintering properties at high loading concentrations, although catalytic performance is significantly lost at lower concentrations (e.g. $2.1 \mathrm{wt} \%, 14.2 \pm 5.5 \mathrm{~nm}$ ). Different anti-sintering mechanisms are proposed for each of the different FDU-12 entrance sizes. Additionally, catalytic data indicates that the obtained 4.5-nm AuNPs supported on FDU-12 with a sub-5-nm entrance size exhibit excellent mass-specific activity (1544 $\left.\mathrm{mmol} \mathrm{g}_{\mathrm{Au}^{-1}} \mathrm{~h}^{-1}\right)$ and selectivity (> 99\%) at $230^{\circ} \mathrm{C}$ for the gas-phase selective oxidation of cyclohexanol.
\end{abstract}

(C) 2017, Dalian Institute of Chemical Physics, Chinese Academy of Sciences. Published by Elsevier B.V. All rights reserved.

\section{Introduction}

Gold nanoparticles (AuNPs) have attracted great interest owing to their valuable potential in many important catalytic reactions, such as hydrogenation of olefins, water gas shift reaction, direct synthesis of hydrogen peroxide and selective alcohol oxidation [1]. The catalytic activities of AuNPs are largely associated with their sizes, atom-packing configuration, crystal facets, and the interface types with supports [2,3]. However, the thermodynamic tendency of AuNPs to grow into larger crystallites, which minimizes their surface energy, is a key obstacle to achieving efficient and sustainable catalytic activity [4-9]. To maintain AuNPs within the desired size range at high temperatures (generally $>300^{\circ} \mathrm{C}$ ), both atom migration (Ostwald ripening) and particle migration need to be controlled during thermal treatment $[10,11]$.

Porous materials have long been used as supports for the preparation of supported AuNP catalysts to improve their thermal stability. There are numerous proposed methods directed at hindering sintering effects caused by particle or atom

\footnotetext{
* Corresponding author. Tel/Fax: +86-571-87952338; E-mail: jfan@zju.edu.cn

This work was supported by the National Natural Science Foundation of China $(21222307,21373181,21403197,91545113,21503189)$, the Fundamental Research Funds for the Central Universities (2014XZZX003-02), Zhejiang Provincial Natural Science Foundation (LY15B030009), and China Postdoctoral Science Foundation (2014M550333, 2015T80636).

DOI: 10.1016/S1872-2067(17)62762-1 | http://www.sciencedirect.com/science/journal/18722067 | Chin. J. Catal., Vol. 38, No. 3, March 2017
} 
migration [12-23]. Generally, the narrow pore dimensions of porous supports enhance the physical barriers that mitigate the rate of particle growth of supported AuNPs [14,24,25]. Additionally, high metal loading should be avoided to suppress particle aggregation by increasing inter-particle distances [26]. Conversely, pore connectivity and structure have been reported to significantly impact NP stability $[14,27,28]$. It has been shown that one-dimensional (1-D) pores are more efficient in restricting particle growth than three-dimension (3-D) pore systems by restraining metal NP transportation [26,27]. However, mass diffusion limitations and pore blockage are more of an issue in 1-D porous systems than their 3-D counterparts.

Prior to this work, we have shown that excellent anti-sintering properties can be achieved at high AuNP loading levels when using the extra-large mesoporous silica, EP-FDU-12 (cage size $>25 \mathrm{~nm}$ ), as the support [29]. The 3-D porous structure of EP-FDU-12 allows two or more AuNPs to reside in every extra-large mesopore at high loading concentrations (> $9 \mathrm{wt} \%$ ). Thus, inter-particle interactions are remarkably strengthened via significant overlapping of the diffusion-spheres of AuNPs and local vapor-particle equilibrium in each cage is possible. In this case, a self-focusing mechanism dominates the particle growth, leading to an obvious suppression of atom migration and therefore outstanding anti-sintering properties. Nevertheless, traditional EP-FDU-12 having larger entrance sizes $(>7$ $\mathrm{nm}$ ) is not able to suppress sintering at low loading concentrations. Following the classic Ostwald ripening mechanism, the AuNPs grow larger after high-temperature calcination.

Herein, we study the sintering resistance properties as a function of FDU-12 pore entrance size. Simple adjustments to the type of organic template and reaction temperature enable the successful synthesis of FDU-12 with controllable entrance sizes $(<3,3-5$ and $7 \mathrm{~nm})$. Different NP growth mechanisms are proposed for each of the different entrance sizes. It is worth noting that stabilized AuNPs having the desired size range over a narrow distribution (4.5-5.0 nm) form after calcination (550 ${ }^{\circ} \mathrm{C}$ in air for $5 \mathrm{~h}$ ) when supported on FDU-12 having a sub-5-nm entrance size. This stabilization is achieved over a wide loading concentration (1.0-8.3 wt\%) in contrast to EP-FDU-12 having a larger entrance size $(7 \mathrm{~nm})$. Catalytic performance of the supported AuNPs is evaluated from gas-phase alcohol selective oxidation reactions. It is shown that the supported Au catalysts with the desired uniform size distribution exhibit excellent mass-specific activity (1544 mmol $\mathrm{g}_{\mathrm{Au}}{ }^{-1} \mathrm{~h}^{-1}$ ) and selectivity (> $99 \%$ ) at $230{ }^{\circ} \mathrm{C}$ for the gas-phase selective oxidation of cyclohexanol, which significantly surpasses previously reported Agor Mn-based catalysts $\left(784 \mathrm{mmol} \mathrm{g}_{\mathrm{Ag}}{ }^{-1} \mathrm{~h}^{-1}, 50 \%\right.$ selectivity and $879 \mathrm{mmol} \mathrm{gMn}^{-1} \mathrm{~h}^{-1}, 70 \%$ selectivity, respectively) [30,31]. Furthermore, AuNP/FDU-12 catalysts show superior long-term stability under the applied reaction conditions.

\section{Experimental}

\subsection{Material preparation}

\subsubsection{Preparation of FDU-12}

Cubic mesoporous silica (FDU-12) with controllable sub-5-nm entrance sizes was synthesized as a function of changes to the type of organic template and synthesis temperature, following previously reported methods [32,33]. In a typical synthesis, $0.50 \mathrm{~g}$ of triblock copolymer $\mathrm{EO}_{132} \mathrm{PO}_{50} \mathrm{EO}_{132}$ (Pluronic F108, BASF), $0.60 \mathrm{~g}$ of 1,3,5-trimethylbenzene (TMB, CP grade, Sinopharm Chemical Reagent Co. Ltd.) and $1.25 \mathrm{~g}$ of $\mathrm{KCl}$ (AR grade, Sinopharm) were dissolved in $50 \mathrm{~mL}$ of $1 \mathrm{~mol} / \mathrm{L}$ hydrochloric acid at $25 \pm 0.1^{\circ} \mathrm{C}$. After stirring for $1 \mathrm{~h}, 2.08 \mathrm{~g}$ of tetraethyl orthosilicate (TEOS, AR grade, Sinopharm) was added to give a molar sol-gel ratio of $0.00136 \mathrm{~F} 108: 0.62 \mathrm{KCl}: 0.37$ TEOS : $0.185 \mathrm{TMB}: 1.85 \mathrm{HCl}: 100 \mathrm{H}_{2} \mathrm{O}$. After stirring for $24 \mathrm{~h}$ at $25 \pm 0.1^{\circ} \mathrm{C}$, the mixture was transferred into an autoclave and heated at a desired temperature for $24 \mathrm{~h}$. For FDU-12(18, 4) (18 and 4 indicate the pore and entrance size, respectively), the hydrothermal temperature was set to $140{ }^{\circ} \mathrm{C}$ and lowered to $100{ }^{\circ} \mathrm{C}$ for FDU-12 $(15,<3)$. The as-made product was obtained by filtration and air-dried at room temperature. The organic template was removed by calcination in air at $350{ }^{\circ} \mathrm{C}$ for $5 \mathrm{~h}$. EP-FDU-12 having larger entrance sizes was synthesized according to our previous report [29].

\subsubsection{Preparation of AuNPs}

The synthesis of AuNPs was similar to the reported method [34]. In a typical synthesis, $100 \mathrm{mg}$ of $\mathrm{AuPPh}_{3} \mathrm{Cl}$ was mixed with $400 \mu \mathrm{L}$ of dodecanethiol ( $\geq 98 \%$, Sigma-Aldrich) in $20 \mathrm{~mL}$ of toluene (AR grade, Sinopharm) to form a clear solution, to which $84 \mathrm{mg}$ of $\mathrm{NaBH}_{4}$ (96\%, Sinopharm) was added in one portion. The mixture was heated with stirring at $55^{\circ} \mathrm{C}$ for $7 \mathrm{~h}$ before the reaction system was cooled to room temperature. AuNPs were precipitated out from the reaction mixture as a black solid powder by addition of $40 \mathrm{~mL}$ of ethanol. The precipitate was separated by centrifugation before washing with ethanol and natural drying.

\subsubsection{Preparation of AuNP/mesoporous silica and $\mathrm{AuNP} / \gamma-\mathrm{Al}_{2} \mathrm{O}_{3}$}

AuNPs were loaded into mesoporous silicas by a colloid deposition method [35]. The desired amount of AuNPs was suspended in $25 \mathrm{~mL}$ of chloroform. To this solution, the desired amount of mesoporous silica was added. After stirring for 1-24 $\mathrm{h}$, the solid product was centrifuged and air-dried. The AuNP/mesoporous silica samples were thermally treated at $550{ }^{\circ} \mathrm{C}$ in air for $5 \mathrm{~h}$ to evaluate their anti-sintering properties and catalytic performance. The preparation of AuNPs on a commercial $\gamma-\mathrm{Al}_{2} \mathrm{O}_{3}(99.9 \%$, Aladdin) was identical to the AuNP/mesoporous silica method, except that the calcination temperature was lowered to $350{ }^{\circ} \mathrm{C}$. AuNP particle size was analyzed by transmission electron microscopy (TEM) and X-ray diffraction (XRD) measurements.

\subsection{Catalytic oxidation of cyclohexanol}

The oxidation of cyclohexanol was performed within an electronically controlled furnace in a fixed bed vertical glass reactor (length $=250 \mathrm{~mm}$, i.d. $=12 \mathrm{~mm}$ ), fitted with a glass frit carrying the catalyst mixed with quartz sand. The oxygen stream $(4 \mathrm{~mL} / \mathrm{min})$ was controlled by a mass flow instrument 
and the liquid reagent $(0.45 \mathrm{~mL} / \mathrm{h})$ was supplied through a syringe pump. Liquid vaporization occurred on the reactor wall prior to the catalytic bed. The products were analyzed by gas chromatography (GC). Selectivity was calculated as moles cyclohexanone product per mole of reacted cyclohexanol and the carbon mass balance was $>99 \%$ in the case where selectivity was $>99 \%$.

\subsection{Characterization}

Small-angle X-ray scattering (SAXS) patterns were recorded using a Xenocs Xeuss-saxs/waxs system. Nitrogen adsorption isotherms were measured at $-196^{\circ} \mathrm{C}$ on a Micromeritics ASAP 2020 adsorption analyzer. Before the adsorption analysis, calcined samples were outgassed under vacuum at $200{ }^{\circ} \mathrm{C}$. TEM micrographs were recorded on a Hitachi HT-7700 microscope operated at $100 \mathrm{kV}$ and a FEI Tecnai G ${ }^{2}$ F20 S-TWIN microscope operated at $200 \mathrm{kV}$. The samples were embedded in epoxy resin and microtomed for TEM imaging. Scanning electron microscopy (SEM) images were taken on a Hitachi SU-8010 microscope operated at $1 \mathrm{kV}$. XRD patterns were recorded on a Ragaku Ultima IV diffractometer using $\mathrm{Cu} K_{\alpha}$ radiation. The average crystal size is derived from the Scherrer equation based on the peak width of the $\mathrm{Au}(111)$ reflection.

\section{Results and discussion}

\subsection{Structure characterization of mesoporous silica}

The ordered 3-D cubic mesostructure of FDU-12 having a narrow entrance size was first confirmed by SAXS measurements (Fig. 1). A typical SAXS pattern of sample FDU-12(18, 4) exhibits six peaks, which can be indexed to the (111), (200), (220), (311), (331) and (531) reflections of an fcc structure $(F m 3 m)$. The cell parameters of FDU-12(18, 4) and FDU-12(15, $<3$ ) are calculated to be 34.5 and $32.3 \mathrm{~nm}$, respectively.

Nitrogen sorption analysis was further utilized to measure their porous structures and textural properties. As shown in Fig. 2, the isotherms of two samples both show a type H4 hysteresis loop with a steep capillary evaporation step at $p / p_{0}=$ 0.45 because of the tensile strength effect $[36,37]$, indicating that the samples have an entrance size smaller than $4.9 \mathrm{~nm}$.

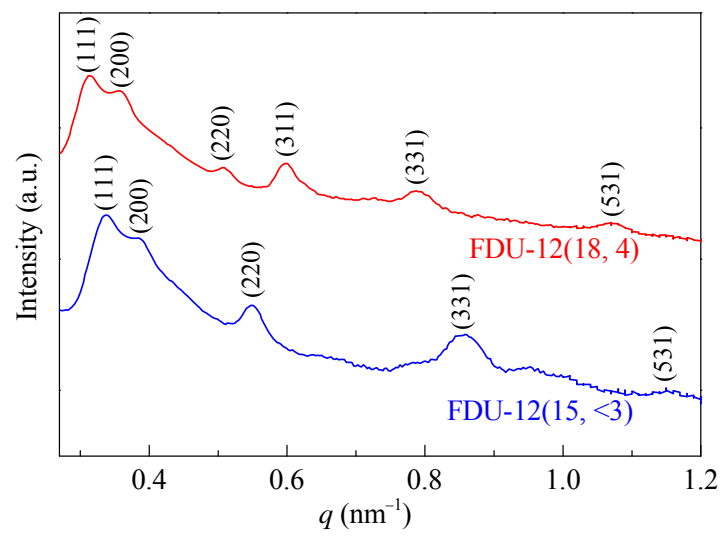

Fig. 1. SAXS patterns of FDU-12(15, <3) and FDU-12(18, 4).

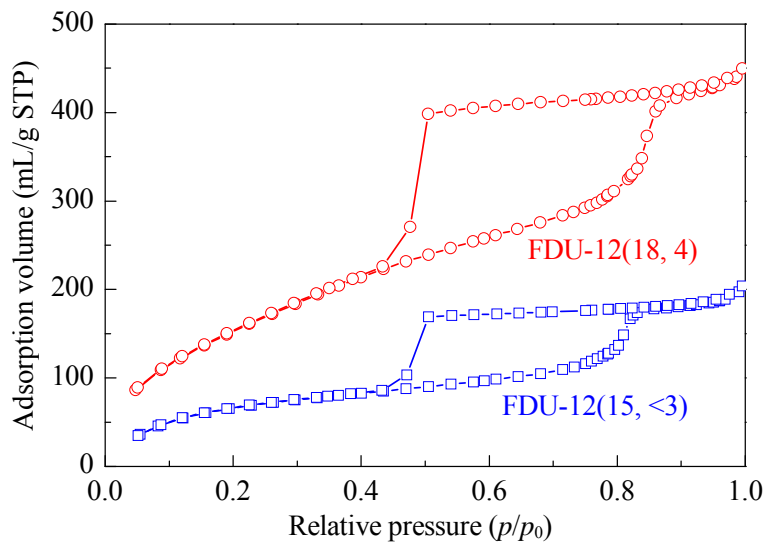

Fig. 2. Nitrogen sorption isotherms of FDU-12(15, <3) and FDU-12(18, 4).

The physicochemical properties of the mesoporous silica supports discussed in this work are listed in Table 1.

TEM images of FDU-12 $(18,4)$ taken along the [110] and [233] directions are shown in Fig. 3(a) and (b), respectively. The cell parameter calculated based on the value of $d(1-11)$ and $d(3-1-1)$ is $34.8 \mathrm{~nm}$, in good agreement with the value derived from SAXS results. Furthermore, the pore size estimated from the diameter of the white disks in Fig. 3(c) is also in

Table 1

Physicochemical properties of mesoporous silica supports.

\begin{tabular}{lccccc}
\hline Sample & $\begin{array}{c}\text { Unit } \\
\text { cell } \\
(\mathrm{nm})\end{array}$ & $\begin{array}{c}\text { Pore } \\
\text { size }^{\text {a }}(\mathrm{nm})\end{array}$ & $\begin{array}{c}\text { Entrance } \\
\text { size }^{\mathrm{b}} \\
(\mathrm{nm})\end{array}$ & $\begin{array}{c}\text { Pore } \\
\text { volume } \\
\left(\mathrm{cm}^{3} / \mathrm{g}\right)\end{array}$ & $\begin{array}{c}\text { BET surface } \\
\text { area }^{2} \\
\left(\mathrm{~m}^{2} / \mathrm{g}\right)\end{array}$ \\
\hline FDU-12(15,<3) & 32.3 & 14.6 & $<3$ & 0.55 & 689 \\
FDU-12(18, 4) & 34.5 & 18.0 & $3-4.9$ & 0.86 & 910 \\
FDU-12(27,7) [29] & 41.7 & 26.5 & 6.9 & 0.74 & 461 \\
\hline
\end{tabular}

a Calculated from the adsorption branch of the $\mathrm{N}_{2}$ sorption isotherm based on the Derjaguin-Broekhoff-de Boer (BdB) sphere model.

b Calculated from the desorption branch of the $\mathrm{N}_{2}$ sorption isotherm based on the BdB sphere model and inferred by the results of probe experiments (discussed later).
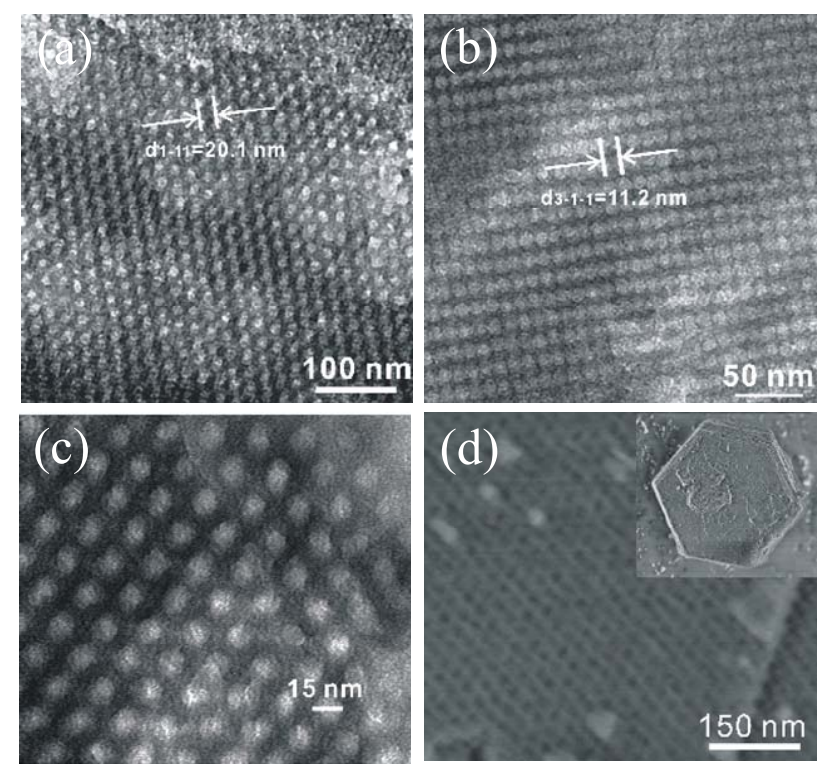

Fig. 3. TEM images of FDU-12(18, 4) viewed from [110] (a) and [233] (b) directions, increased magnification (c). (d) SEM image of FDU-12(18, 4). 


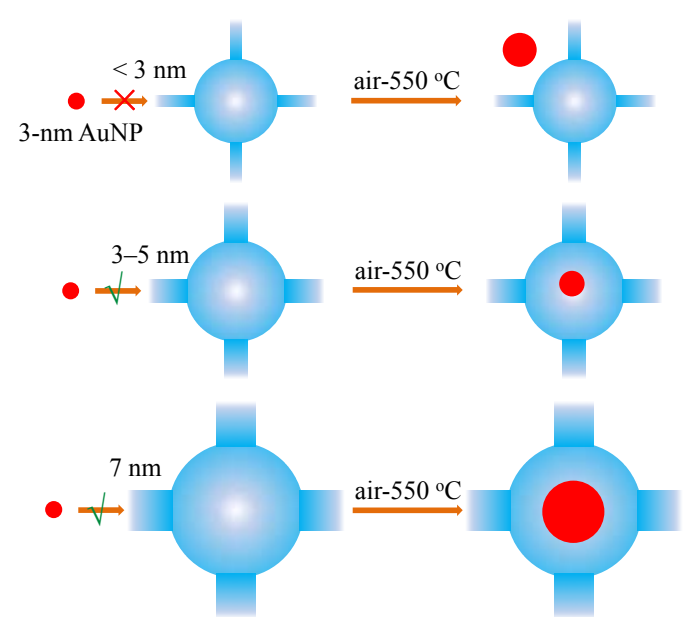

Scheme 1. Illustration for probing entrance size and particle growth process after calcination at relatively low loading concentration.

agreement with the $\mathrm{N}_{2}$ sorption measurement $(18.0 \mathrm{~nm})$. As shown in the SEM image in Fig. 3(d), FDU-12(18, 4) displays a hexagonal prism-like morphology with open pores.

\subsection{Anti-sintering properties as a function of entrance size}

To further determine the entrance size of FDU-12(15, <3) and FDU-12(18, 4), which is beyond the detection limit of the nitrogen sorption measurements $(<4.9 \mathrm{~nm})$, we tactfully use 3-nm AuNPs as a probe (Scheme 1) [38]. The pre-synthesized AuNPs have a uniform size of $3.0 \pm 0.4 \mathrm{~nm}$ (Fig. 4). Entrance size can be determined by observing if the 3-nm AuNPs have ingress to the cage-like pores or not. As shown in Fig. 5(a) and (b), the overwhelming majority of AuNPs are located on the external surface of FDU-12(15, <3), indicating that the entrance size of FDU- $12(15,<3)$ is smaller than $3 \mathrm{~nm}$. In contrast to FDU-12(15, <3), 3-nm AuNPs disperse evenly within the cages of FDU-12(18, 4) (Fig. 5(e) and (f)), suggesting that its entrance size is large enough to allow full ingress into the large cages. TEM observations together with the textural properties de-

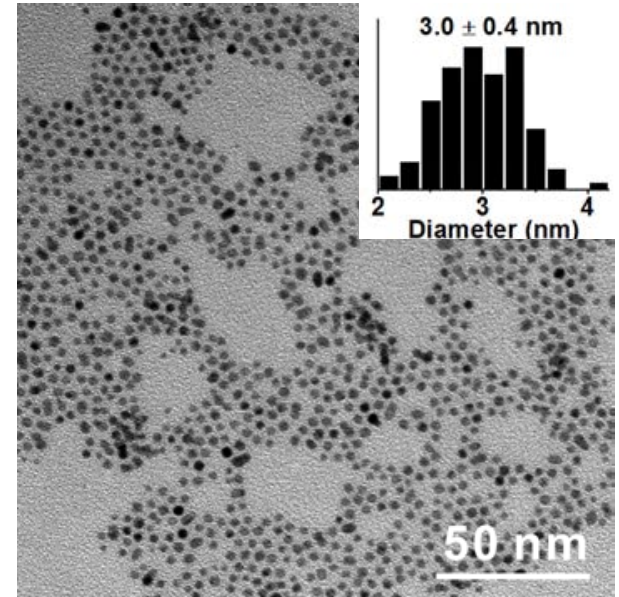

Fig. 4. TEM image of 3-nm monodispersed Au nanoparticles (AuNPs) together with the size distribution (inset).

rived from sorption measurements strongly suggest that the entrance size of FDU-12(18, 4) is in the range of 3-5 nm. Difference between the entrance sizes of the two FDU-12 samples is also reflected in their AuNP adsorption capacity [39]. AuNPs can only be adsorbed on the external surface of FDU-12(15, $<3$ ), whereas they are readily accessible to the large internal surface of FDU-12(18, 4) and are accommodated within the cages. As a result, at the same loading level ( $\sim 6 \mathrm{wt} \%$ AuNPs), uptake onto FDU-12 $(18,4)$ is stoichiometric (loading concentration $6.0 \mathrm{wt} \%$ determined by ICP element analysis), while a final product loading level of $1.0 \mathrm{wt} \%$ is observed for FDU-12 $(15,<3)$ even after vigorous stirring for $24 \mathrm{~h}$.

The location of the AuNPs on the FDU-12 supports has a significant influence on their thermal stability (Scheme 1). After thermal treatment at $550^{\circ} \mathrm{C}$ in air for $5 \mathrm{~h}$, the AuNPs residing in the cages grow from 3 to $4.5 \mathrm{~nm}$ (Fig. 5(g)), whereas the size of the AuNPs on the external surface is $\sim 6.0 \mathrm{~nm}$ (Fig. 5(c)). Their different thermal stability is also confirmed by XRD analysis (Fig. 6). The AuNPs outside of the cages are $2.8 \mathrm{~nm}$ larger than those entrapped within the cages.
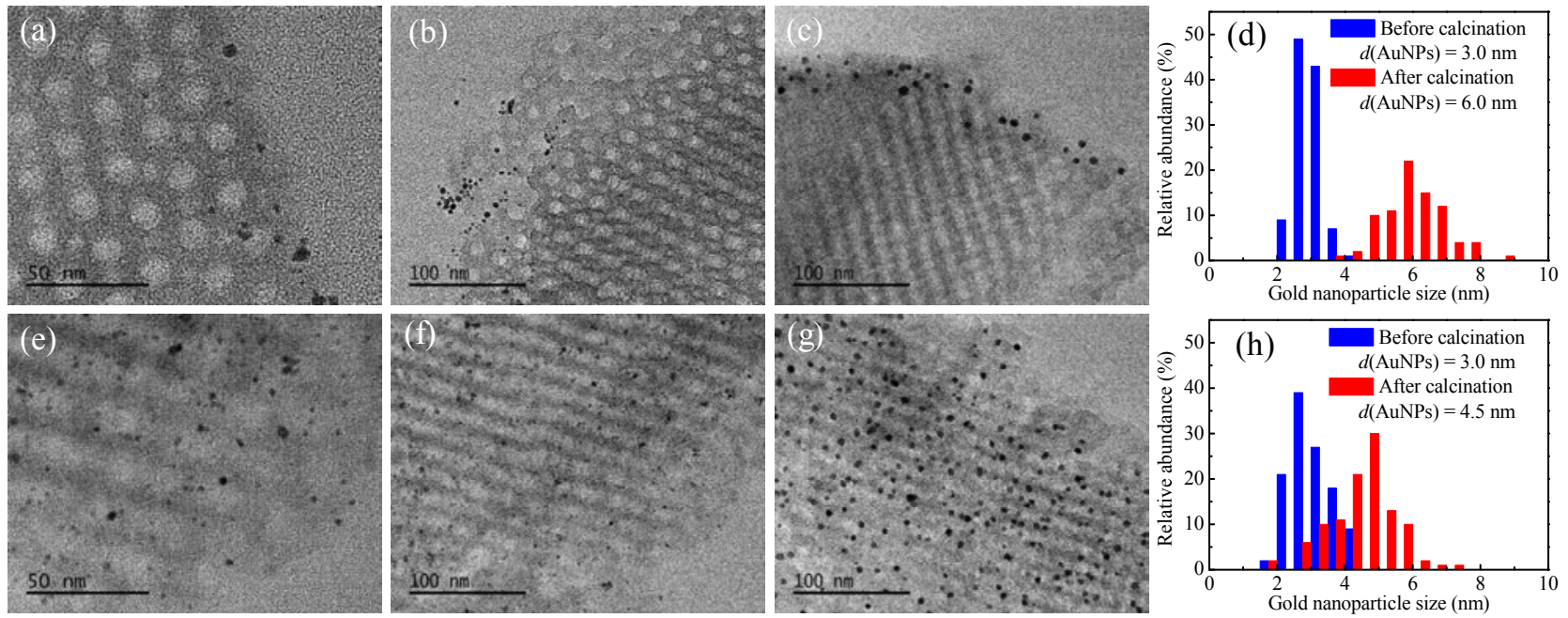

Fig. 5. TEM images and AuNP size distributions for $1.0 \mathrm{wt} \%$ AuNP/FDU-12(15, <3) (a-d) and $6.0 \mathrm{wt} \%$ AuNP/FDU-12(18, 4) (e-h) before (a, b, e, f) and after $(\mathrm{c}, \mathrm{g})$ calcination at $550{ }^{\circ} \mathrm{C}$ in air for $5 \mathrm{~h}$. 


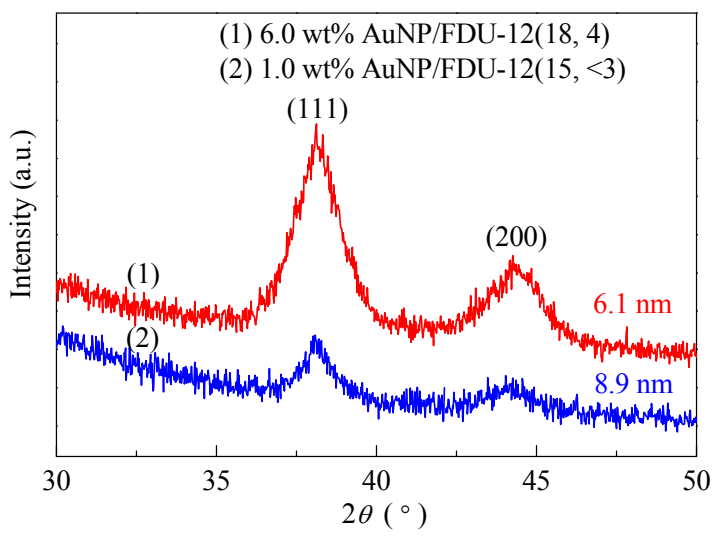

Fig. 6. XRD patterns of AuNPs supported on FDU-12(18, 4) and FDU- $12(15,<3)$ after calcination at $550^{\circ} \mathrm{C}$ in air for $5 \mathrm{~h}$.

The thermal stability of AuNPs within FDU-12(18, 4) is studied as a function loading concentration (1.0-8.3 wt\%). After thermal treatment, the AuNP size is maintained in the range of 4.5-5.0 $\mathrm{nm}$ regardless of the initial loading concentration (Fig. 7). All observed sizes are smaller than the corresponding AuNPs supported on FDU-12(15, <3). In addition to TEM analysis, XRD measurements on AuNP/FDU-12(18, 4) reveal a consistent AuNP size irrespective of the loading level as calculated by the Scherrer equation based on the peak width of the $\mathrm{Au}(111)$ reflection (Fig. 8), confirming that the thermal stability of AuNPs entrapped within FDU-12 $(18,4)$ is not influenced by AuNP loading concentration. This behaviour is completely different from most traditional porous supports, where NPs are observed to grow larger as a function of increased loading concentration because of reduced particle-to-particle distance $[40,41]$.

Fig. 9 summarizes the statistical size distribution results of
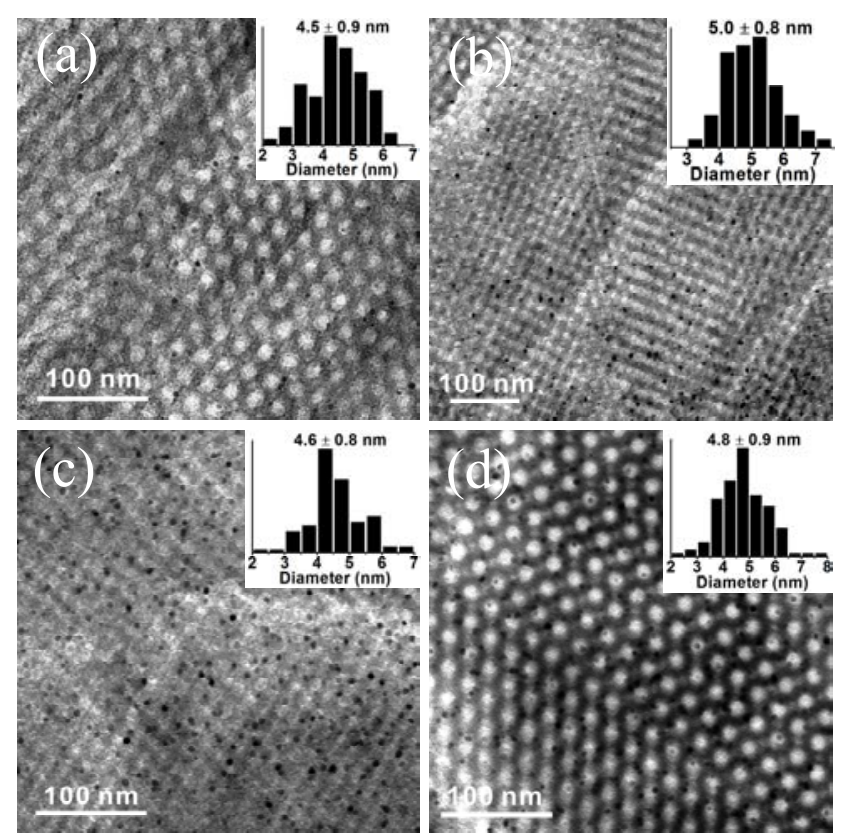

Fig. 7. TEM images of 1.0 (a), 1.8 (b), 4.7 (c) and 8.3 wt\% (d) AuNP/FDU-12 $(18,4)$ after calcination at $550{ }^{\circ} \mathrm{C}$ in air for $5 \mathrm{~h}$ (inset shows the corresponding size distribution).

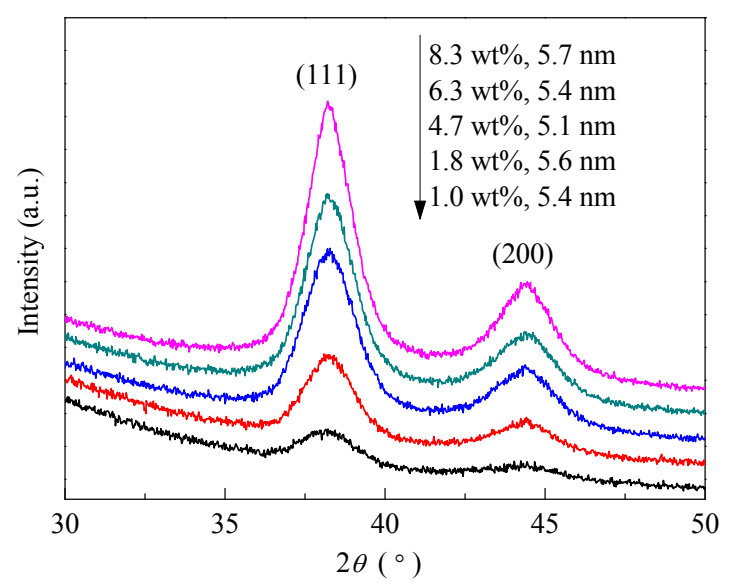

Fig. 8. XRD patterns of AuNP/FDU-12(18, 4) as a function of loading concentration.

AuNPs supported on FDU-12 as a function of entrance size and loading concentration. At a high loading concentration $>9$ $w t \%)$, the self-focusing mechanism narrows the particle distribution and reduces the driving force for Ostwald ripening, thereby assisting the AuNP/FDU-12(27, 7) system to quickly reach dynamic equilibrium, ultimately resulting in the promising thermal stability of AuNPs within FDU-12(27, 7) [29]. At a low loading (e.g. $2.1 \mathrm{wt} \%$ ), the majority of the FDU-12(27, 7) cages are vacant. Au vapor or small AuNPs residing within a cage can diffuse through the large entrance of the cage, which significantly hinders the system from reaching saturation vapor pressure as given by the Gibbs-Thompson equation, leading to uncontrolled particle growth $(14.2 \pm 5.5 \mathrm{~nm})$. However, when FDU-12(18, 4) is used as the support, AuNPs larger than $5 \mathrm{~nm}$ will not be able to diffuse to another cage because of the dimension limitations of the small entrance size. Additionally, the existence of large cages increases, to a degree, inter-particle distances and small entrance sizes weaken atom migration. As a result, the AuNPs entrapped within FDU-12(18, 4) can be stabilized over a tight size distribution (4.5-5.0 nm) across a

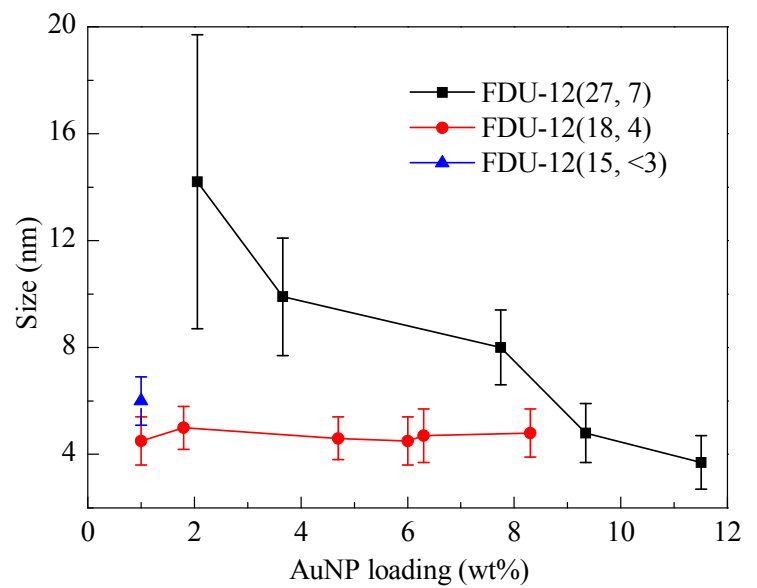

Fig. 9. Particle size distribution (TEM results) of AuNPs supported on FDU-12(15, <3), FDU-12(18, 4) and FDU-12 $(27,7)$ as a function of AuNP loading after calcination at $550{ }^{\circ} \mathrm{C}$ in air for $5 \mathrm{~h}$. Data for FDU-12(27, 7) was taken from Ref. [29]. 
wide loading concentration (1.0-8.3 wt\%).

\subsection{Catalytic oxidation of cyclohexanol}

Supported AuNPs are promising catalysts for selective alcohol oxidation $[42,43]$. For some alcohol molecules (e.g. benzyl alcohol, ethanol), only AuNPs within a certain size range will exhibit promising catalytic activity $[44,45]$. Thus, stabilization of AuNPs within a desirable size range is critical for specific catalytic applications. In our previous work, we observed that 5-6 nm AuNPs show optimum activity for gas-phase selective oxidation of cyclohexanol to cyclohexanone [46].

In this work, activity was studied as a function of AuNP loading onto FDU-12 supports and a commercial $\gamma-\mathrm{Al}_{2} \mathrm{O}_{3}$ for comparison. Catalytic reactions were evaluated by probing the gas-phase selective oxidation of cyclohexanol. Each reaction was duplicated, however, using a different $\mathrm{Au}$ catalyst mass, each within a fixed bed vertical glass reactor having the same cross sectional area. As shown in Fig. 10, the similar activities for the selected two catalysts at the equivalent contact times (0.267-1.425 g s/mL) suggest that the diffusion effect has been eliminated (1.069 $\mathrm{g} \mathrm{s} / \mathrm{mL})$.

Fig. 11 shows the catalytic performance of four Au-supported FDU-12 catalysts as a function of entrance size. 4.5-nm AuNPs entrapped within FDU-12 $(18,4)$ having a controlled size distribution exhibit optimal activity (1544 mmol $\mathrm{g}_{\mathrm{Au}}{ }^{-1} \mathrm{~h}^{-1}$ at $230{ }^{\circ} \mathrm{C}$ ). Activity almost doubles (825 mmol $\mathrm{g}_{\mathrm{Au}}{ }^{-1}$ $\mathrm{h}^{-1}$ ) for AuNPs located on the external surface of FDU-12(15, $<3$ ), which have an average particle size as large as $6.0 \mathrm{~nm}$. At low loading concentrations, the AuNPs supported within FDU-12(27, 7) have a much larger size of $9.9 \mathrm{~nm}$ and present the lowest activity $\left(171 \mathrm{mmol} \mathrm{g}_{\mathrm{Au}}{ }^{-1} \mathrm{~h}^{-1}\right.$ at $\left.230{ }^{\circ} \mathrm{C}\right)$, which corresponds to only $11 \%$ of the AuNP/FDU-12(18, 4) activity. A similar trend is observed at lower reaction temperatures (180 and $210{ }^{\circ} \mathrm{C}$ ). Furthermore, the catalytic data provides direct evidence to optimize activity by tuning of the AuNP size as a function of calcination temperature. In this study, $550{ }^{\circ} \mathrm{C}$ is the optimal temperature for thermal treatment. If the thermal treatment temperature is lowered to $450{ }^{\circ} \mathrm{C}$, the AuNP size within FDU-12(18, 4) decreases from 4.5 to $3.9 \mathrm{~nm}$. As a result, the catalytic activity of the resulting catalyst lowers to 663

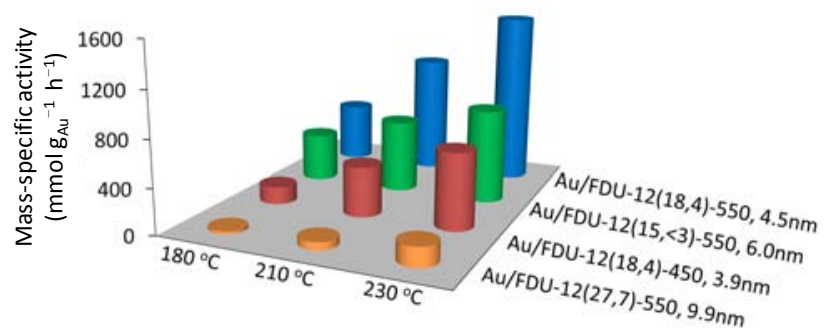

Fig. 11. Mass-specific activity (mmol $\left.\mathrm{g}_{A u}{ }^{-1} \mathrm{~h}^{-1}\right)$ of size-controlled supported AuNPs (450 and 550 indicate the calcination temperature, ${ }^{\circ} \mathrm{C}$ ) in the gas-phase cyclohexanol selective oxidation performed at different temperatures (selectivity $>$ 99\%).

mmol $g_{A u} u^{-1} \mathrm{~h}^{-1}$ at $230{ }^{\circ} \mathrm{C}$. Catalyst development herein further proves that stabilizing active metal particles within a desired size range is vitally important to fully realize their catalytic function. Furthermore, the mass-specific activity of $4.5-\mathrm{nm}$ AuNPs supported on tailored FDU-12 silica significantly surpasses previously reported Ag- and Mn-based catalysts (784

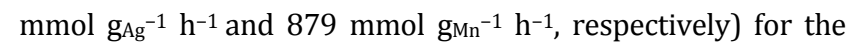
gas-phase selective oxidation of cyclohexanol [30,31] and Ruand $\mathrm{Au}$-based catalysts $\left(224 \mathrm{mmol} \mathrm{g}_{\mathrm{Ru}}{ }^{-1} \mathrm{~h}^{-1}\right.$ and $645 \mathrm{mmol} \mathrm{g}_{\mathrm{Au}}{ }^{-1}$ $\mathrm{h}^{-1}$, respectively) for the liquid-phase selective oxidation of cyclohexanol $[47,48]$.

To compare with the AuNP/FDU-12 system, the catalytic activity of $1.0 \mathrm{wt} \% \mathrm{AuNP} / \gamma-\mathrm{Al}_{2} \mathrm{O}_{3}$ was tested. After calcination at $350{ }^{\circ} \mathrm{C}$ for $5 \mathrm{~h}$, AuNPs on $\gamma-\mathrm{Al}_{2} \mathrm{O}_{3}$ were observed at $4.1 \pm 1.4 \mathrm{~nm}$ (Fig. 12(a)). Catalytic conversion and selectivity of the obtained AuNP $/ \gamma-\mathrm{Al}_{2} \mathrm{O}_{3}$ catalyst are shown in Fig. 12(b). Although cyclohexanol conversion corresponding to the $1.0 \mathrm{wt} \%$ $\mathrm{AuNP} / \gamma-\mathrm{Al}_{2} \mathrm{O}_{3}$ and $1.0 \mathrm{wt} \%$ AuNP/FDU-12(18, 4) - $4.5 \mathrm{~nm}$ systems is similar ( $23.7 \%$ vs. $22.2 \%$ at $210{ }^{\circ} \mathrm{C}$, respectively), the selectivity of $1.0 \mathrm{wt} \% \mathrm{AuNP} / \gamma-\mathrm{Al}_{2} \mathrm{O}_{3}$ is significantly worse (34.0\% by-products at $\left.210{ }^{\circ} \mathrm{C}\right)$. Increasing the reaction temperature to $230{ }^{\circ} \mathrm{C}$, dehydration of cyclohexanol is increasingly favored (52.9\% by-products), which likely relates to the Lewis acid sites of $\gamma-\mathrm{Al}_{2} \mathrm{O}_{3}$ [49-51].

Furthermore, we investigated the catalytic stability of 1.0 wt $\%$ AuNP/FDU-12(18, 4)-4.5 $\mathrm{nm}$ and $1.0 \mathrm{wt} \%$ AuNP/FDU$12(15,<3)-6.0 \mathrm{~nm}$ under the applied reaction conditions. As shown in Fig. 13(a), no obvious deactivation is observed in
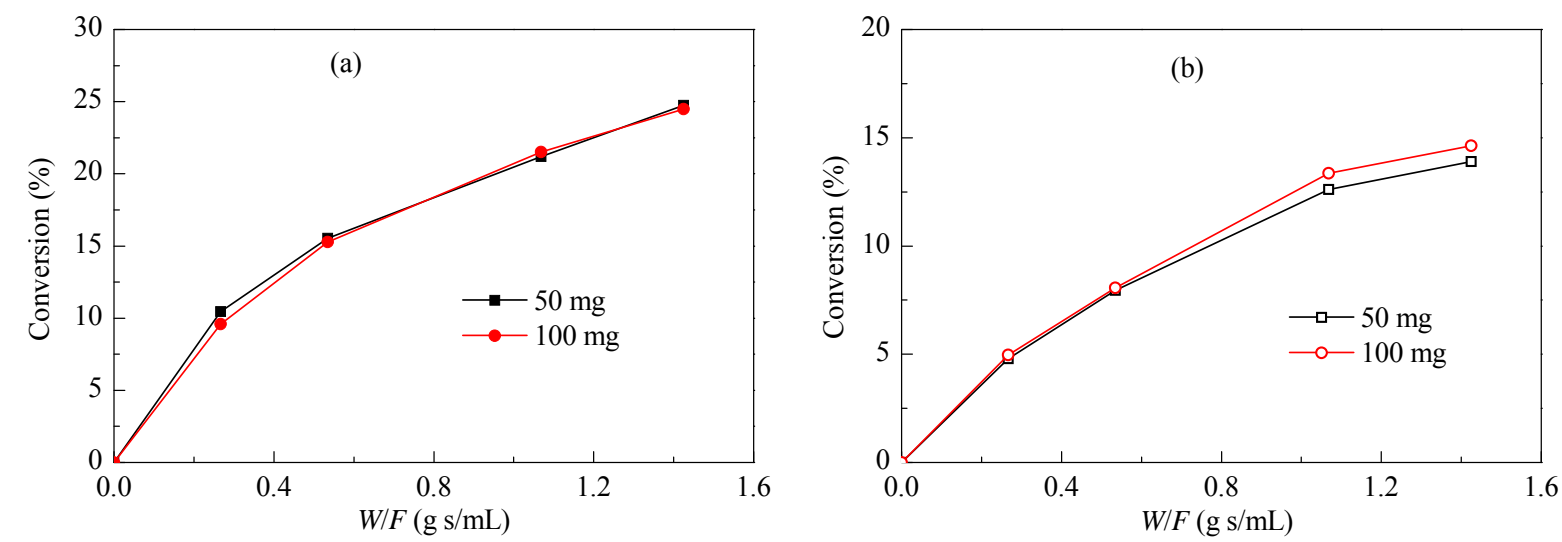

Fig. 10. Cyclohexanol conversion as a function of contact time at $210^{\circ} \mathrm{C}$ based on different catalysts. (a) $1.0 \mathrm{wt} \%$ AuNP/FDU-12(18, 4)-4.5 nm; (b) 1.0 wt $\%$ AuNP/FDU-12(15, <3)-6.0 nm. 

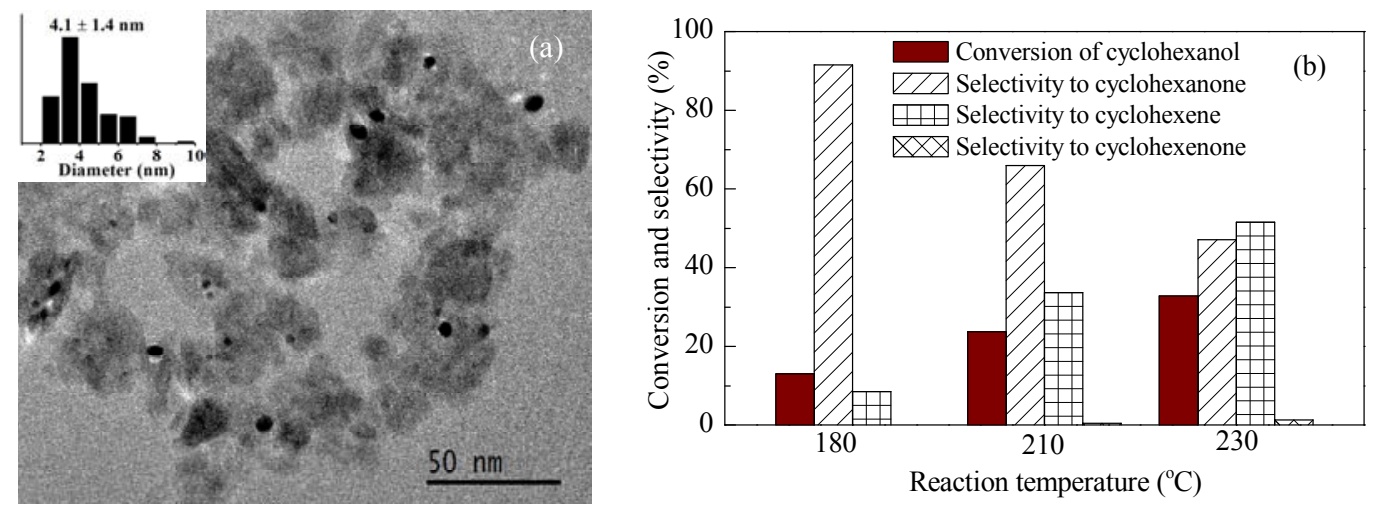

Fig. 12. (a) TEM image of $1.0 \mathrm{wt} \% \mathrm{AuNP} / \gamma-\mathrm{Al}_{2} \mathrm{O}_{3}$ after calcination at $350^{\circ} \mathrm{C}$ in air for $5 \mathrm{~h}$ (inset shows the corresponding size distribution). (b) Catalytic properties of $1.0 \mathrm{wt} \% \mathrm{AuNP} / \gamma-\mathrm{Al}_{2} \mathrm{O}_{3}$ in the gas-phase selective oxidation of cyclohexanol as a function of temperature.
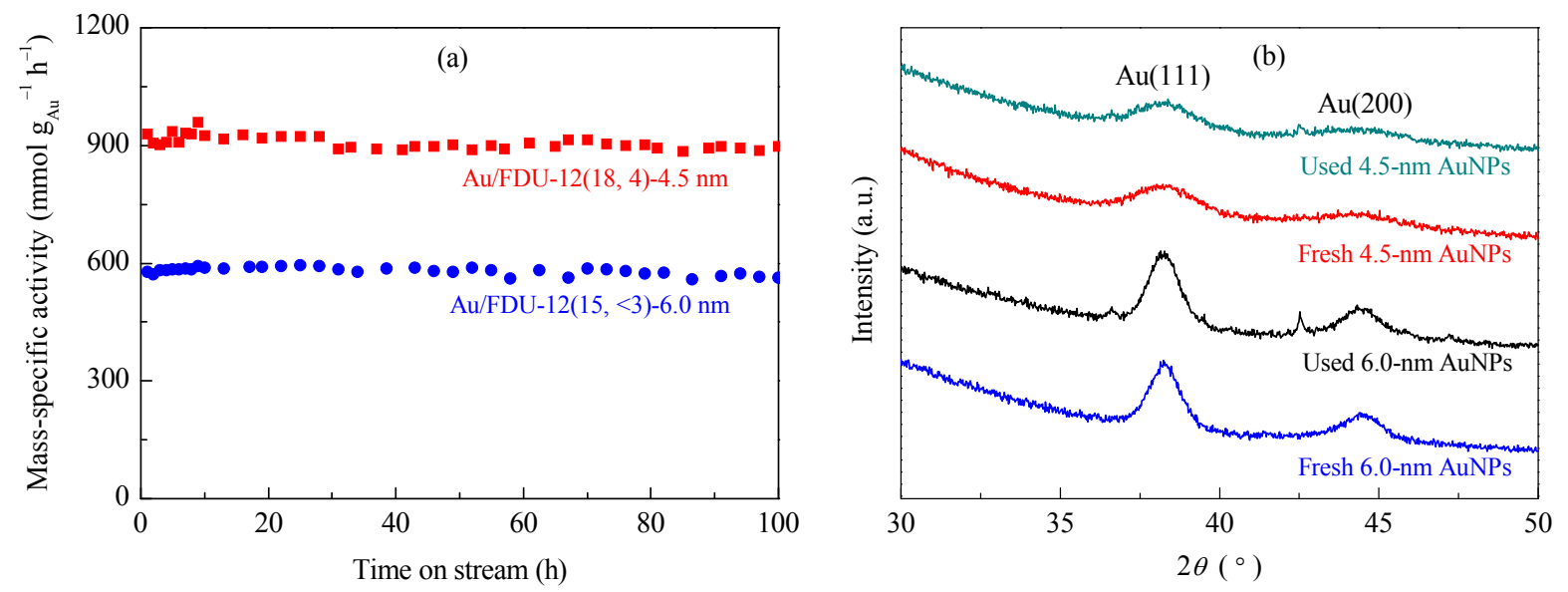

Fig. 13. (a) Time-on-stream mass-specific activity of $1.0 \mathrm{wt} \%$ AuNP/FDU-12(18, 4)-4.5 nm and $1.0 \mathrm{wt} \%$ AuNP/FDU- $12(15,<3)-6.0 \mathrm{~nm}$ performed at $210^{\circ} \mathrm{C}$. (b) XRD patterns of fresh and used AuNP/FDU-12 catalysts.

both catalysts during a time-on-stream of $100 \mathrm{~h}$ at $210^{\circ} \mathrm{C}$ (only $3.4 \%$ and $4.1 \%$ activity loss after $100 \mathrm{~h}$ for $4.5-\mathrm{nm}$ and $6.0-\mathrm{nm}$ AuNPs, respectively). Additionally, the particle sizes of the fresh and used AuNPs derived from the Scherrer equation taken from XRD analysis (Fig. 13(b)) are near identical (5.1 vs. $5.3 \mathrm{~nm}$ and 8.5 vs. $8.6 \mathrm{~nm}$ ), which further indicates that AuNP/FDU-12 catalysts are very stable under reaction conditions for alcohol oxidation.

\section{Conclusions}

We have successfully synthesized cubic mesoporous silica (FDU-12) with controllable entrance sizes and studied their impact on AuNP anti-sintering. Additionally, our work reveals the entrance size for 3-D cage-like mesoporous supports has significant influence on the particle growth. FDU-12(27, 7) shows promising anti-sintering properties at high loading concentrations because of the self-focusing mechanism, which suppresses atom migration; however, at low loading concentrations poor performance is observed. In contrast, FDU-12(18, 4) is able to stabilize AuNPs within the desired size range over a wide loading concentration. The unique 3-D cage-like pores with tailored narrow entrance size act as excellent physical barriers to particle mobility and therefore hinder particle coa- lescence efficiently. Furthermore, 4.5-nm AuNPs stabilized within FDU-12(18, 4) exhibit excellent activity and long-term stability in the gas-phase selective oxidation of cyclohexanol. It is expected that the outcome of this work will help in the design of highly efficient and durable catalysts for applications where strict control of the metal particle size is key to application optimization [52-56].

\section{References}

[1] A. S. K. Hashmi, G. J. Hutchings, Angew. Chem. Int. Ed., 2006, 45, 7896-7936.

[2] L. Guczi, A. Beck, Z. Pászti, Catal. Today, 2012, 181, 26-32.

[3] P. Priecel, H. A. Salami, R. H. Padilla, Z. Zhong, J. A. Lopez-Sanchez, Chin. J. Catal., 2016, 37, 1619-1650.

[4] M. Haruta, CATTECH, 2002, 6, 102-115.

[5] A. Corma, P. Concepcion, I. Dominguez, V. Forne, M. Sabater, J. Catal., 2007, 251, 39-47.

[6] Y. J. Hao, Y. Z. Chong, S. R. Li, H. Q. Yang, J. Phys. Chem. C, 2012, 116, 6512-6519.

[7] R. Zanella, V. Rodríguez-González, Y. Arzola, A. Moreno-Rodriguez, ACS Catal., 2012, 2, 1-11.

[8] J. Wang, A. H. Lu, M. R. Li, W. P. Zhang, Y. S. Chen, D. X. Tian, W. C. Li, ACS Nano, 2013, 7, 4902-4910.

[9] M. Y. Miao, J. T. Feng, Q. Jin, Y. F. He, Y. N. Liu, Y. Y. Du, N. Zhang, D. 


\section{Graphical Abstract}

Chin. J. Catal., 2017, 38: 545-553 doi: 10.1016/S1872-2067(17)62762-1

Gold nanoparticle stabilization within tailored cubic mesoporous silica: Optimizing alcohol oxidation activity

Wei Hong, Xiaoqing Yan, Renhong Li, Jie Fan* Zhejiang University; Zhejiang Sci-Tech University

FDU-12 having a sub-5-nm entrance size stabilizes gold nanoparticles over a controlled narrow size distribution across a wide loading concentration during heat-treatment, thus optimizing their catalytic properties in the gas-phase selective oxidation of cyclohexanol.

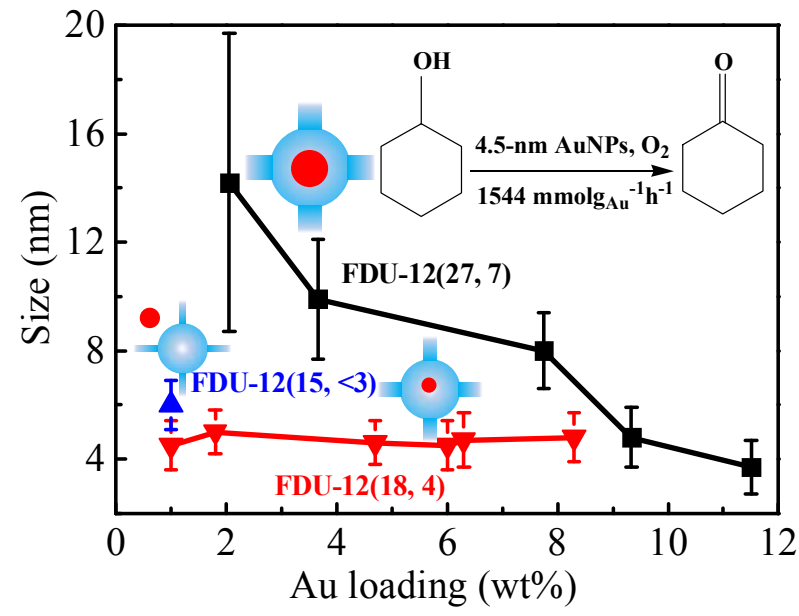

Q. Li, RSC Adv., 2015, 5, 36066-36074.

[10] P. Wynblatt, N. A. Gjostein, Prog. Solid State Chem., 1975, 9, 21-58.

[11] C. H. Bartholomew, Appl. Catal. A, 2001, 212, 17-60.

[12] W. F. Yan, S. M. Mahurin, Z. W. Pan, S. H. Overbury, S. Dai, J. Am. Chem. Soc., 2005, 127, 10480-10481.

[13] P. M. Arnal, M. Comotti, F. Schüth, Angew. Chem. Int. Ed., 2006, 45, 8224-8227.

[14] J. P. Gabaldon, M. Bore, A. K. Datye, Top. Catal., 2007, 44, 253-262.

[15] X. Q. Huang, C. Y. Guo, J. Q. Zuo, N. F. Zheng, G. D. Stucky, Small, 2009, 5, 361-365.

[16] S. H. Joo, J. Y. Park, C. K. Tsung, Y. Yamada, P. D. Yang, G. A. Somorjai, Nat. Mater, 2009, 8, 126-131.

[17] B. Lee, Z. Ma, Z. Zhang, C. Park, S. Dai, Microporous Mesoporous Mater., 2009, 122, 160-167.

[18] A. Cao, G. Veser, Nat. Mater., 2010, 9, 75-81.

[19] Y. Q. Dai, B. Lim, Y. Yang, C. M. Cobley, W. Li, E. C. Cho, B. Grayson, P. T. Fanson, C. T. Campbell, Y. Sun, Y. N. Xia, Angew. Chem. Int. Ed., 2010, 49, 8165-8168.

[20] M. C. Saint-Lager, I. Laoufi, A. Bailly, O. Robach, S. Garaudée, P. Dolle, Faraday Discuss., 2011, 152, 253-265.

[21] T. T. Zhang, H. Y. Zhao, S. N. He, K. Liu, H. Y. Liu, Y. D. Yin, C. B. Gao, ACS Nano, 2014, 8, 7297-7304.

[22] U. Jeong, J. B. Joo, Y. Kim, RSC Adv., 2015, 5, 55608-55618.

[23] H. J. Chen, C. Liu, M. Wang, C. F. Zhang, G. Li, F. Wang, Chin. J. Catal,, 2016, 37, 1787-1793.

[24] W. F. Yan, B. Chen, S. M. Mahurin, E. W. Hagaman, S. Dai, S. H. Overbury, J. Phys. Chem. B, 2004, 108, 2793-2796.

[25] T. Asefa, R. B. Lennox, Chem. Mater., 2005, 17, 2481-2483.

[26] G. Prieto, J. Zečević, H. Friedrich, K. P. de Jong, P. E. de Jongh, Nat. Mater., 2013, 12, 34-39.

[27] M. T. Bore, H. N. Pham, E. E. Switzer, T. L. Ward, A. Fukuoka, A. K. Datye, J. Phys. Chem. B, 2005, 109, 2873-2880.

[28] G. Prieto, M. Shakeri, K. P. de Jong, P. E. de Jongh, ACS Nano, 2014, 8, 2522-2531.

[29] X. Q. Yan, X. J. Wang, Y. Tang, G. C. Ma, S. H. Zou, R. H. Li, X. G. Peng, S. Dai, J. Fan, Chem. Mater., 2013, 25, 1556-1563.

[30] J. Shen, W. Shan, Y. H. Zhang, J. M. Du, H. L. Xu, K. N. Fan, W. Shen, Y. Tang, J. Catal., 2006, 237, 94-101.

[31] D. Santhanaraj, C. Suresh, P. Vijayan, N. Venkatathri, K. Shanthi, Reac. Kinet. Mech. Catal., 2010, 99, 439-446.
[32] J. Fan, C. Z. Yu, F. Gao, J. Lei, B. Z. Tian, L. M. Wang, Q. Luo, B. Tu, W. Z. Zhou, D. Y. Zhao, Angew. Chem. Int. Ed., 2003, 42, 3146-3150.

[33] G. C. Ma, X. Q. Yan, Y. L. Li, L. P. Xiao, Z. J. Huang, Y. P. Lu, J. Fan, J. Am. Chem. Soc., 2010, 132, 9596-9597.

[34] N. F. Zheng, J. Fan, G. D. Stucky, J. Am. Chem. Soc., 2006, 128, 65506551.

[35] N. F. Zheng, G. D. Stucky, J. Am. Chem. Soc., 2006, 128, 1427814280.

[36] M. Kruk, M. Jaroniec, Chem. Mater., 2001, 13, 3169-3183.

[37] J. C. Groen, L. A. A. Peffer, J. Pérez-Ramírez, Microporous Mesoporous Mater., 2003, 60, 1-17.

[38] M. Kruk, V. Antochshuk, J. R. Matos, L. P. Mercuri, M. Jaroniec, J. Am. Chem. Soc., 2002, 124, 768-769.

[39] X. J. Wang, X. Q. Yan, R. H. Li, L. P. Xiao, G. C. Ma, Y. H. Dai, J. Fan, J. Nanosci. Nanotechnol., 2015, 15, 7060-7067.

[40] W. Q. Zou, R. D. Gonzalez, Appl. Catal. A, 1993, 102, 181-200.

[41] H. Shinjoh, M. Hatanaka, Y. Nagai, T. Tanabe, N. Takahashi, T. Yoshida, Y. Miyake, Top. Catal., 2009, 52, 1967-1971.

[42] C. Della Pina, E. Falletta, L. Prati, M. Rossi, Chem. Soc. Rev., 2008, 37, 2077-2095.

[43] H. Koga, K. Sakata, Y. Ato, A. Hayashi, K. Tada, M. Okumura, Chin. J. Catal., 2016, 37, 1588-1593.

[44] P. Haider, B. Kimmerle, F. Krumeich, W. Kleist, J. D. Grunwaldt, A. Baiker, Catal. Lett., 2008, 125, 169-176.

[45] K. Q. Sun, S. W. Luo, N. Xu, B. Q. Xu, Catal. Lett., 2008, 124, 238-242.

[46] X. Q. Yan, [PhD Thesis], Zhejiang University, Hangzhou, 2013.

[47] K. Yamaguchi, N. Mizuno, New J. Chem., 2002, 26, 972-974.

[48] P. F. Zhang, Z. A. Qiao, X. G. Jiang, G. M. Veith, S. Dai, Nano Lett., 2015, 15, 823-828.

[49] A. Ebadi, N. Safari, M. H. Peyrovi, Appl. Catal. A, 2007, 321, 135-139.

[50] S. Roy, G. Mpourmpakis, D. Y. Hong, D. G. Vlachos, A. Bhan, R. J. Gorte, ACS Catal., 2012, 2, 1846-1853.

[51] J. F. De Wilde, H. Chiang, D. A. Hickman, C. R. Ho, A. Bhan, ACS Catal., 2013, 3, 798-807.

[52] J. H. Kim, D. J. Suh, T. J. Park, K. L. Kim, Appl. Catal. A, 2000, 197, 191-200.

[53] K. O. Christensen, D. Chen, R. Lødeng, A. Holmen, Appl. Catal. A, 2006, 314, 9-22. 
[54] T. M. Eggenhuisen, P. Munnik, H. Talsma, P. E. de Jongh, K. P. de Jong, J. Catal., 2013, 297, 306-313.

[55] G. H. Layan Savithra, E. Muthuswamy, R. H. Bowker, B. A. Carrillo,
M. E. Bussell, S. L. Brock, Chem. Mater., 2013, 25, 825-833.

[56] B. B. Chen, X. B. Zhu, Y. D. Wang, L. M. Yu, C. Shi, Chin. J. Catal., 2016, 37, 1729-1737.

\title{
稳定于具有亚 $5 \mathrm{~nm}$ 窗口的立方介孔氧化硅的金纳米颗粒及其优异的醇氧化活性
}

\author{
洪 伟, 间晓庆 ${ }^{\mathrm{b}}$, 李仁宏 ${ }^{\mathrm{a}, \mathrm{b}}$, 范 杰, ${ }^{\mathrm{a}}{ }^{*}$ \\ $\mathrm{a}^{\mathrm{a}}$ 浙江大学化学系浙江省应用化学重点实验室, 浙江杭州 310027

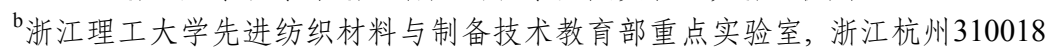

摘要: 金纳米颗粒在烯烃加氢、水气转化、过氧化氢直接合成和醇类选择性氧化等反应中表现出独特的催化性能, 引起了 人们广泛关注. 通常, 金纳米颗粒的催化活性受到尺寸、原子堆积形式、暴露晶面及其与载体的相互作用所影响. 而金纳 米颗粒的烧结往往导致其催化效率迅速下降. 为了解决金颗粒烧结问题, 提高其使用寿命, 必须控制高温处理时颗粒和原 子的迁移. 尽管已有很多工作见诸报道, 然而到目前为止, 仍未完全解决金颗粒烧结问题.

本文通过调整有机模板剂和反应温度成功地合成了不同窗口尺寸的立方介孔氧化硅材料(FDU-12), 并将预先合成的3 $\mathrm{nm}$ 金颗粒负载于其上, 考察了窗口尺寸对金颗粒烧结的影响. 首先, 采用小角X射线散射、氮气吸附-脱附、透射电镜和扫 描电镜等手段证实成功合成了具有亚 $5 \mathrm{~nm}$ 窗口的FDU- 12 材料, 同时以 $3 \mathrm{~nm}$ 金颗粒为探针, 进一步区分了具有 $<3 \mathrm{~nm}$ 和 $3-5$ $\mathrm{nm}$ 窗口的FDU-12样品. 在抗烧结实验中发现, 具有3-5 nm窗口尺寸的FDU-12能够在一个较宽的金负载量 $(1.0-8.3 \mathrm{wt} \%)$ 下 稳定金纳米颗粒. 在 $550^{\circ} \mathrm{C}$ 空气中焙烧 $5 \mathrm{~h}$ 后, 金颗粒的平均尺寸维持在 $4.5-5.0 \mathrm{~nm}$. 更小的窗口尺寸则会导致 $3 \mathrm{~nm}$ 金颗粒 无法进入FDU-12孔道, 从而带来低的负载能力和差的抗烧结性能. 另一方面, 具有 $>7 \mathrm{~nm}$ 窗口尺寸的FDU-12则只在高的 金颗粒负载量( $>9 \mathrm{wt} \%)$ 下才表现出较好的抗烧结性能, 低负载量时烧结严重 $(2.1 \mathrm{wt} \%, 14.2 \pm 5.5 \mathrm{~nm})$.

我们推测, 合适的窗口尺寸 (3-5 nm) 恰好能允许 $3 \mathrm{~nm}$ 金颗粒进入FDU-12的孔道, 在高温处理过程中, 当金颗粒长大到 5 $\mathrm{nm}$ 左右时, 窗口极大地限制了金颗粒的移动, 导致其不能在孔与孔之间自由迁移. 此外, 该FDU-12材料的孔径为 $18 \mathrm{~nm}$, 这 使得封装在各个孔内部的金颗粒与其他金颗粒距离较远, 不利于其通过原子迁移而发生烧结. 因此, 拥有 3-5 nm窗口尺寸 的FDU-12在一个宽的金负载量下表现出良好的抗烧结能力. 而对于具有 $>7 \mathrm{~nm}$ 窗口尺寸的FDU-12, 在高的金负载量下, 它可通过自聚焦效应抑制原子迁移, 从而具有优良的抗烧结性能. 但在低负载量时, 介孔氧化硅的绝大部分孔内并不包含 多个金颗粒, 自聚焦效应无法发挥作用, 在高温焙烧时金颗粒可以通过大的窗口尺寸相互融合导致烧结.

我们将具有不同金尺寸的AuNP/FDU-12催化剂用于环己醇选择性氧化反应中. 结果表明, $4.5 \mathrm{~nm}$ 的金催化剂表现出最 好的活性 $\left(1544 \mathrm{mmol} \mathrm{g}_{\mathrm{Au}}{ }^{-1} \mathrm{~h}^{-1}\right)$ 和大于 $99 \%$ 的选择性 $\left(230^{\circ} \mathrm{C}\right)$, 大大超过了先前报道的基于 $\mathrm{Ag}$ 和 $\mathrm{Mn}$ 为活性中心的催化剂. 另 外, 与负载在商用 $\gamma-\mathrm{Al}_{2} \mathrm{O}_{3}$ 上相比, AuNP/FDU-12体系表现出了很好的选择性, 直接脱水产物小于 $1 \%$. 同时可以保持 $100 \mathrm{~h}$ 内 金颗粒不发生烧结, 活性不明显下降.

关键词: 金纳米颗粒; 立方介孔氧化硅; 窗口尺寸；抗烧结性能; 醇氧化

收稿日期: 2016-10-20. 接受日期: 2016-12-06. 出版日期: 2017-03-05.

*通讯联系人. 电话/传真: (0571)87952338; 电子信箱: jfan@zju.edu.cn

基金来源：国家自然科学基金(21222307，21373181，21403197，91545113，21503189); 中央高校基本科研业务费专项资金 (2014XZZX003-02); 浙江省自然科学基金(LY15B030009); 中国博士后科学基金(2014M550333, 2015T80636).

本文的英文电子版由Elsevier出版社在ScienceDirect上出版(http://www.sciencedirect.com/science/journal/18722067). 